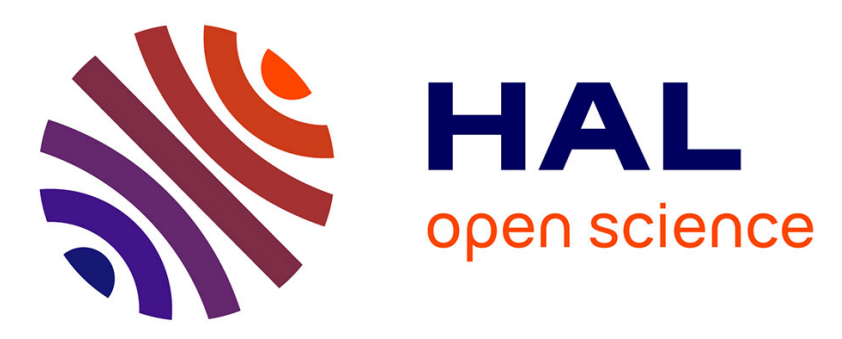

\title{
Genotoxic effects of exposure to waterborne uranium, dietary methylmercury and hyperoxia in zebrafish assessed by the quantitative RAPD-PCR method
}

\author{
Adelaide Lerebours, Sébastien Cambier, Lindsay Hislop, Christelle
}

Adam-Guillermin, Jean-Paul Bourdineaud

\section{To cite this version:}

Adelaide Lerebours, Sébastien Cambier, Lindsay Hislop, Christelle Adam-Guillermin, Jean-Paul Bourdineaud. Genotoxic effects of exposure to waterborne uranium, dietary methylmercury and hyperoxia in zebrafish assessed by the quantitative RAPD-PCR method. Mutation Research - Genetic Toxicology and Environmental Mutagenesis, 2013, 755 (1), pp.55-60. 10.1016/j.mrgentox.2013.05.012 . hal-02155173

\section{HAL Id: hal-02155173 \\ https://hal.science/hal-02155173}

Submitted on 13 Jun 2019

HAL is a multi-disciplinary open access archive for the deposit and dissemination of scientific research documents, whether they are published or not. The documents may come from teaching and research institutions in France or abroad, or from public or private research centers.
L'archive ouverte pluridisciplinaire HAL, est destinée au dépôt et à la diffusion de documents scientifiques de niveau recherche, publiés ou non, émanant des établissements d'enseignement et de recherche français ou étrangers, des laboratoires publics ou privés. 
Genotoxic effects of exposure to waterborne uranium, dietary methylmercury and hyperoxia in zebrafish assessed by the quantitative RAPD-PCR method.

Adélaïde Lerebours ${ }^{1,2}$, Sébastien Cambier ${ }^{3}$, Lindsay Hislop ${ }^{3}$, Christelle Adam-Guillermin ${ }^{1}$, Jean-Paul Bourdineaud ${ }^{3 *}$

${ }^{1}$ Laboratoire d'Ecotoxicologie des Radionucléides, Institut de Radioprotection et de Sûreté Nucléaire, Bât 186, BP 3, 13115 Saint-Paul-Lez-Durance Cedex, France

${ }^{2}$ Present address: Department of Biological Sciences, University of Hull, Cottingham Road, Hull, HU6 7RX, United Kingdom

${ }^{3}$ Arcachon Marine Station, UMR 5805, CNRS, Université de Bordeaux, Place du Dr Peyneau, 33120 Arcachon, France

*Corresponding author: Pr Jean-Paul Bourdineaud, e-mail: jp.bourdineaud@epoc.ubordeaux1.fr, phone number: +33 (0) 556223 926, fax number: +33 (0) 556549383

Keywords: probe's hybridization sites; DNA damage; environmental stressors; fish 


\begin{abstract}
Release of chemicals and fluctuation in oxygen content in the aquatic environment represent hazards for fish health. The present study aims at assessing the genotoxic impact of low concentration exposures to waterborne uranium (U), dietary methyl mercury (MeHg) and hyperoxia in zebrafish by using the RAPD-PCR quantitative method. A significant increase of the number hybridization sites was observed in fish exposed to $30 \mu \mathrm{g} \mathrm{U} / \mathrm{L}$ and $100 \mu \mathrm{g} \mathrm{U} / \mathrm{L}$ and hyperoxia. In fish exposed to $\mathrm{MeHg}(13.5 \mu \mathrm{g} \mathrm{Hg} / \mathrm{g}$, dry weight) no change in the number of hybridization sites were found, however, the frequency of PCR products showed significant variation. The mechanisms of toxicity leading to DNA damage in fish exposed to waterborne uranium, mercury and hyperoxia are discussed and the results from the literature given by the comet assay, micronucleus test and RAPD-PCR method compared. The study provides new data regarding the genotoxic effects of $\mathrm{MeHg}$, hyperoxia and low $\mathrm{U}$ concentrations (30 $\mu \mathrm{g} \mathrm{U} / \mathrm{L})$ in fish. The present work highlights the use of the RAPD-PCR as a sensitive method in the assessment of chemically-induced DNA damage in animals.
\end{abstract}




\section{Introduction}

Centuries of emissions of anthropogenic mercury $(\mathrm{Hg})$ have caused widespread environmental contamination over large regions of the Earth [1]. $\mathrm{Hg}$ and especially methylmercury $(\mathrm{MeHg})$ have been reported as hazardous environmental pollutants with severe risks for animal and human health and are responsible for a specific range of neurological diseases [2]. $\mathrm{MeHg}$ pollution is also considered as a continuous environmental hazard to human health, especially via fish consumption. However, there is a clear lack of data on the genotoxic impact of exposure to $\mathrm{MeHg}$ in fish. One study showed up-regulations of rad51 gene involved in DNA repair in zebrafish after 21 and 63 days of exposure to 13.5 $\mu \mathrm{g}$ of $\mathrm{Hg} / \mathrm{g}$, dry weight (dw) [3].

Uranium (U), a naturally occurring element and a member of the actinide series, is widely distributed throughout the environment. The natural concentrations found in freshwater systems are highly variable and range from $0.01 \mu \mathrm{g} / \mathrm{L}$ to over $2 \mathrm{mg} / \mathrm{L}$, depending on the geological background [4]. Various anthropogenic contributions originating from the nuclear fuel cycle, farming, research laboratories and military activities may considerably enhance U levels in terrestrial and aquatic ecosystems [4].

In vitro exposure to high $\mathrm{U}$ concentrations ( 0.238 to $59.5 \mathrm{mg} \mathrm{U} / \mathrm{L}$ ) showed an increase in the production of double strand breaks in embryonic zebrafish fibroblasts [5]. In erythrocytes of zebrafish exposed to 20,100 and $500 \mu \mathrm{g}$ U/L during 20 days, DNA damage was observed for the highest U concentration [6]. In zebrafish exposed to 20 and $100 \mu \mathrm{g} \mathrm{U} / \mathrm{L}$ the expression of gadd and rad51 genes involved in the repair of DNA damage is modified [7]. According to previous studies [6,7], the in vivo genotoxic effect of low U concentration exposures warrant further investigation. 
The aquatic environment is characterized by daily and seasonal fluctuation in the oxygen content. Hyperoxic conditions occur naturally and are also used in aquaculture systems. The exposure to hyperoxia induced a perturbation of the oxidative balance in different fish species such as rainbow trout Oncorhynchus mykiss [8], goldfish C. auratus, Atlantic salmon Salmo salar [9], Senegal sole Solea senegalensis [10], and common carp Cyprinius carpio [11]. Despite the evidence that hyperoxia stimulates the generation of free radicals, there is a lack of data on the corresponding induction of genotoxic damage.

The present study aims at assessing DNA damage in zebrafish exposed to U, a radioelement, $\mathrm{MeHg}$, a methylated metal and hyperoxia by using the RAPD-PCR method. A laboratory experiment was set up in which zebrafish were contaminated through diet, using food containing $13.5 \mu \mathrm{g}$ of $\mathrm{Hg} / \mathrm{g}$. This mercury concentration corresponds to that found in various preys of the food web in French Guiana [12]. Another laboratory experiment consisted in contaminating zebrafish by low waterborne depleted uranium concentrations: 30 and $100 \mu \mathrm{g} \mathrm{U} / \mathrm{L}$. The lowest one is close to the provisional drinking water guideline value of the World Health Organization (15 $\mu \mathrm{g} \mathrm{U} / \mathrm{L})$ [13]. The exposure to hyperoxia was achieved by introducing $\mathrm{O}_{2}$ in bags representing $1 / 3$ of the total volume. Fish were kept in hyperoxia conditions during 10 hours. The question we want to address is whether or not the quantitative RAPD-PCR method will detect an effect of exposure to these stressors.

\section{Material and Methods}

\subsection{Uranium exposure conditions}

Adult male zebrafish (body weight: $0.70 \pm 0.08 \mathrm{~g}$ wet weight (ww); standard length: $3.33 \pm 0.14 \mathrm{~cm}$ ) were obtained from a French supplier (Exomarc, Lormont, France). Fish were randomly placed in three continuous flow-through tanks of chlorine-free oxygenated water and acclimated to laboratory conditions for three weeks before the experiment. Water 
temperature was maintained at $24.5 \pm 0.3{ }^{\circ} \mathrm{C}$, and the $\mathrm{pH}$ at 6.4 . Fish were fed once a day with a quantity of standard fish pellets corresponding to $2 \%$ of the fish body weight (ww). Tank bottoms were cleaned every day to eliminate fish feces and food remains. Fish were contaminated with waterborne $\mathrm{U}$ at nominal concentration of $30 \mu \mathrm{g} \mathrm{U} / \mathrm{L}$ and $100 \mu \mathrm{g} \mathrm{U} / \mathrm{L}$ by a continuous flow-through system. These concentrations were selected because we have already performed studies at such levels showing gene expression pattern modification, histopathological damage and the onset of an oxidative stress in several tissues [6,7,14-17]. The stock solution of $\mathrm{U}$ used was prepared from uranyl nitrate $\mathrm{UO}_{2}\left(\mathrm{NO}_{3}\right)_{2} 6 \mathrm{H}_{2} \mathrm{O}(\mathrm{Sigma}$, France). Ten fish per condition were removed after 28 days of exposure and were killed within second by immersion in melting ice $\left(\mathrm{T}=0^{\circ} \mathrm{C}\right)$. There were no detectable macroscopic effects of uranium exposures on the health of the fish.

\subsection{Methylmercury exposure conditions}

Adult male zebrafish (body weight: $0.88 \pm 0.03 \mathrm{~g}$ wet weight (ww); standard length: $3.63 \pm 0.05 \mathrm{~cm}$ ) were randomly placed in two continuous flow-through tanks of chlorine-free oxygenated water and acclimated to laboratory conditions for two weeks before the experiments. Water temperature was maintained at $24 \pm 0.5^{\circ} \mathrm{C}$. Fish were fed twice a day with a quantity of artificial food corresponding to $2.5 \%$ of the fish body weight (ww). Control fish were fed with non contaminated food. Tank bottoms were cleaned every day to eliminate fish feces and food remains. In the exposure tank, fish were fed with $\mathrm{MeHg}$ contaminated food containing $13.5 \mu \mathrm{g}$ of $\mathrm{Hg} / \mathrm{g}$ (dry wt), making a contamination pressure of $0.6 \mu \mathrm{g}$ of $\mathrm{Hg} /$ fish/day. Contaminated diet was prepared by mixing artificial fish food (Dr. Bassleer biofish, Telte, the Netherlands) with an ethanolic solution of MeHg chloride (Alltech) as previously described [3]. Ten fish per condition were removed after 50 days of exposure and were killed within second by immersion in melting ice $\left(\mathrm{T}=0{ }^{\circ} \mathrm{C}\right)$. There were no detectable macroscopic effects of methylmercury exposure on the health of the fish. A 50 
days-long exposure was chosen because we have observed mitochondrial and histopathological outcomes after such duration at that concentration $[18,19]$.

\subsection{Oxygen exposure conditions}

Fish were kept in plastic bags inflated with pure oxygen at a proportion of $1 / 3$ of the total volume of the bag leading to fill plastic bags with $5 \mathrm{~L}$ of chlorine-free water and $2.5 \mathrm{~L}$ of pure oxygen. Plastic bags were successively inflated and deflated twice by pure oxygen bubbling, and were finally inflated by a third bubbling of pure oxygen to obtain a pure oxygen atmosphere before sealing. Bags were kept in polystyrene tank to keep the temperature at $24^{\circ} \mathrm{C}$. During the hyperoxic exposure, the oxygen partial pressure varied in between 47 to $60 \mathrm{kPa}$. After 10 hours of exposure to hyperoxia fifteen fish were removed for genotoxic analysis along with 15 control fish from the same original pool collected from a non-exposed tank. Among the 15 fish collected per group, 10 were for RAPD-PCR analysis, and 5 for the micronucleus test. In another independent bag 5 fish were submitted to hyperoxic treatment for $10 \mathrm{~h}$ and then were transferred to a normoxic tank for recovery. Three days after these 5 last fish were collected for the micronucleus test. We took care to treat fish to hyperoxia at the same animal density than control fish ( 2 fish per litre) to avoid crowding effect, which could result in a physiological stress response (through the cortisol route), and in turn introduce a bias in the study. Neither external sign of disease nor mortality was recorded at the end of the experiment.

\subsection{Metal quantification}

Uranium and mercury were quantified in fish tissues as already described by Lerebours et al., (2009) [7] and Gonzalez et al., (2005) [3] respectively. Data are presented in Tables S1 and S2.

2.5 Quantification of genotoxic damages by RAPD-PCR and analysis of the melting temperature curves of random amplified PCR products 
Genomic DNA isolation was performed by mincing frozen entire fish with a scalpel. Ten fish per condition coming from the same tank were used and each fish was examined individually. Then crushed tissues were digested overnight at $50{ }^{\circ} \mathrm{C}$ with $10 \mathrm{~mL}$ per gram of tissue of DNA extraction buffer: $10 \mathrm{mM}$ tris $\mathrm{pH}$ 8, $100 \mathrm{mM}$ EDTA $\mathrm{pH}$ 8, 0.5\% SDS, and 200 $\mu \mathrm{g} / \mathrm{mL}$ proteinase $\mathrm{K}$ (Promega). The DNA solution was treated with $100 \mu \mathrm{g} / \mathrm{mL}$ RNAse A (Qiagen) during $2 \mathrm{~h}$ at $37{ }^{\circ} \mathrm{C}$. Genomic DNA was purified by a conventional phenol/chloroform method [20]. Phenol was stabilized and protected against oxidation by addition of $0.1 \%$ of 8-hydroxyquinoline, which in turn warrants the safety of genomic DNA.

Primers used for RAPD-PCRs were the decamer oligonucleotides OPB7 (5'GGTGACGCAG-3') and OPB11 (5'-GTAGACCCGT-3'), which were obtained from Sigma-Proligo. Each $20 \mu \mathrm{L}$ reaction contained $16 \mathrm{ng}$ of genomic DNA, primer at a final concentration of $600 \mathrm{nM}$ and $16 \mu \mathrm{L}$ of PCR mix. Real-time RAPD-PCRs were performed using a Lightcycler system (Roche) and following the program: one cycle at $95^{\circ} \mathrm{C}$ for $10 \mathrm{~min}$ and 50 amplification cycles at $95^{\circ} \mathrm{C}$ for $5 \mathrm{~s}, 50^{\circ} \mathrm{C}$ for $5 \mathrm{~s}$, and $72^{\circ} \mathrm{C}$ for $30 \mathrm{~s}$. The annealing temperature was also increased to $60^{\circ} \mathrm{C}$ for PCR runs using the $\mathrm{OPB} 7$ probe. The dissociation curves were obtained by following the SybrGreen fluorescence level during gradual heating of the PCR products from 60 to $95^{\circ} \mathrm{C}$.

Melting temperature curves analysis was performed using the LightCycler Software 3.5 (Roche). For a given RAPD-PCR reaction, the melting temperature $(T m)$ of each PCR product peak was obtained in order to establish a distribution of the frequencies of appearance of peaks having equal $\mathrm{Tm}$ among a set of 10 different temperature intervals ranging from 78 to $89^{\circ} \mathrm{C}$. The comparison of distributions between two different exposure conditions designates temperature intervals for which the frequency of the PCR products for a known $T m$ differed. 
For each genomic DNA, quantitative analysis relied on the cycle numbers necessary to enter in the exponential phase of the PCR, Ct, using probe OPB7 and OPB11. These probes were successfully used in previous studies [21-23]. To quantify the number of hybridization sites per genome unit of a RAPD probe, reference PCRs were also made with each genomic DNA using 2 oligonucleotide probes flanking the 5' and 3' regions of the fifth exon of the $\beta$-actin 1 gene and therefore complementary to the fourth and fifth introns, respectively. These were 5'-CGTTTGCTTTTATTGGTGCAGG-3' and 5'GAAAATGGGCAGGTGCATCACC-3' for the upstream and downstream probes, respectively. This allows normalization of the amount of template DNA present in each PCR reaction, for the threshold cycle obtained with the $\beta$-actin probes, $\operatorname{Ct}(\beta$-actin), is just indicating four hybridization events per genome unit (two probes on each of $2 \beta$-actin loci). Indeed, when $\Delta=\mathrm{Ct}(\beta$-actin $)-\mathrm{Ct}(\mathrm{OPB} 7)=0$, the RAPD probe allows the same amount of amplified PCR bands, and therefore displays the same number of hybridization sites (HS) per genome units than the $\beta$-actin probes, making $4 \mathrm{HS}$ or $2^{0+2}$; when $\Delta=1$, the probe presents per genome units twice as much HS than the $\beta$-actin probes, making 8 HS or $2^{3}=2^{1+2}$; when $\Delta=3$, the probe presents per genome units 8 -times more HS than the $\beta$-actin probes, making 32 HS or $2^{5}=2^{3+2}=2^{\Delta_{+2}}$; when $\Delta=\mathrm{n}$, the probe presents per genome units $2^{\mathrm{n}}$-times more HS than the $\beta$-actin probes, making $2^{\mathrm{n}+2}=2^{\Delta_{+2}}$. Therefore, the number of hybridization sites per genome unit of a RAPD probe, is $2^{(\mathrm{Ct}(\beta-\mathrm{actin})-\mathrm{Ct}(\mathrm{OPB} 7)+2)}$, or $2^{\Delta_{+2}}$ where $\mathrm{Ct}(\mathrm{OPB} 7)$ is the threshold cycle value of a single RAPD-PCR performed with the OPB7 probe. We did the same to calculate the number of hybridization sites for OPB11, swapping $\mathrm{Ct}(\mathrm{OPB} 7)$ for $\mathrm{Ct}(\mathrm{OPB} 11)$ in the formula.

\subsection{Micronucleus test}

Five fish were used for each test group. Blood was taken from each specimen through a 
puncture in the caudal vein, using a syringe treated with EDTA $0.5 \mathrm{M} \mathrm{pH} 8$, and smeared onto ethanol-cleaned slides. After fixation in pure ethanol for $20 \mathrm{~min}$, the slides were allowed to air-dry, and then the smears were stained for 10 min with Giemsa stain as recommended by the manufacturer (réactifs RAL, ref. 320310, Martillac, France). After $24 \mathrm{~h}$ of solidification, 4 slides per animal were scored, and 500 cells per slide were analyzed. The number of micronucleated erythrocytes out of the 2000 (4x500) erythrocytes examined was counted for each specimen. Micronuclei were counted with a Leica light microscope equipped with an oil-immersion lens at $1200 \mathbf{x}$ magnification. Criteria for micronuclei were as follows: (a) maximum size of micronuclei must not exceed $30 \%$ of the main nucleus; (b) micronuclei and nuclei should stain similarly; (c) micronuclei should be clearly separated from the nucleus. Results were recorded as percentage of cells containing micronuclei relative to the total number of counted cells.

\subsection{Statistical analyses}

The non-parametric Kruskal-Wallis test was performed as a first instance. When significant a Mann-Whitney $U$ test was used to evaluate significant difference between data from an exposed condition versus the corresponding control one $(*$ : $p<0.05)$. For micronucleus assay only, statistical significance was assessed by means of the Chi Square test with Yates correction.

\section{Results}

\subsection{Fish exposed to uranium}

After 28 days of exposure, the number of hybridisation sites significantly increased in fish exposed to $\mathrm{C} 1$ (mean number of sites per genome: $365.10^{-6}$ ) and $\mathrm{C} 2$ (mean number of sites per genome: $800.10^{-6}$ ) U concentrations as compared to controls (mean number of sites per genome: $68.10^{-6}$ ) (Table 1). The highest number was found for fish exposed to the highest exposure concentration using OPB7 probe and a hybridisation temperature of $60^{\circ} \mathrm{C}$. The 
OPB11 probe was tested at $60^{\circ} \mathrm{C}$ but it could not hybridize to DNA at such high annealing temperature. No change was found using OPB7 and OPB11 probes at a hybridisation temperature of $50^{\circ} \mathrm{C}$. Table 2 indicates a significant increase in the frequency of appearance of PCR products using $\mathrm{OPB} 7$ and a hybridization temperature of $60^{\circ} \mathrm{C}$ in the temperature interval [86-87[ for fish exposed at $\mathrm{C} 1$ and $\mathrm{C} 2$ conditions. A significant decrease was found for the temperature interval $[87-88$ [ for fish exposed to $\mathrm{C} 2$ condition.

\subsection{Fish exposed to MeHg}

Table 3 and 4 combine the analysis of $\mathrm{MeHg}$ and hyperoxia because the exposed fish were compared to the same control fish. After 49 days of exposure to $0.6 \mu \mathrm{g} \mathrm{of} \mathrm{Hg} / \mathrm{fish} / \mathrm{day}$ no change was found in the number of hybridization sites using OPB7 and hybridization temperatures of $50^{\circ} \mathrm{C}$ and $60^{\circ} \mathrm{C}$, and using $\mathrm{OPB} 11$ and a hybridization temperature of $50^{\circ} \mathrm{C}$ (Table 3). Table 4 indicates a significant increase and a significant decrease in the frequency of appearance of PCR products using OPB7 and an hybridization temperature of $60^{\circ} \mathrm{C}$ in the temperature intervals $[75-76[$ and [76-77[ respectively (Table 4). A significant decrease was found in the interval $\left[74-75\right.$ [ using OPB11 and an hybridization temperature of $50^{\circ} \mathrm{C}$ (Table 4).

\subsection{Fish exposed to hyperoxia}

In order to compare the RAPD-PCR results with another established method underscoring genotoxic outcomes, 5 fish submitted to the hyperoxic treatment were processed for the micronucleus test, whereas 5 other fish were allowed to recover for 3 days after hyperoxic treatment. The average counts of micronucleated cells found in 1000 red blood cells were $1.2 \pm 0.4,3.6 \pm 0.5$ and $1.8 \pm 0.4$ for control fish, fish treated for $10 \mathrm{~h}$ to hyperoxia and fish allowed to recover for 3 days, respectively. Differences were statistically significant $(p<0.05)$ between hyperoxia-treated fish and the two other groups of fish (control and those let to recover). No significant difference exists between control fish and those let to recover 
for 3 days. These results confirm the RAPD-PCR results and indicate that fish quickly recover from hyperoxia-induced DNA damage.

After 10 hours of exposure to hyperoxia a significant increased in the mean number of hybridization sites per genome $\left(371.10^{-6}\right)$ was observed as compared to control $\left(30.10^{-6}\right)$ (Table3). This was using OPB7 and a hybridisation temperature of $60^{\circ} \mathrm{C}$. A significant decrease occurred in exposed fish $\left(4.8 .10^{-3}\right)$ as compared to controls $\left(7.3 .10^{-3}\right)$ when using OPB11 and a hybridisation temperature of $50^{\circ} \mathrm{C}$. No change in the appearance of PCR products in each temperature interval was noticed (Table 4).

\section{Discussion}

\subsection{Genotoxic effects of Uranium}

In the present study, exposures to uranium induce a significant increase of the mean number of hybridisation sites per genome in fish exposed to uranium concentrations as low as 30 and $100 \mu \mathrm{g}$ U/L. The mechanisms of U-induced DNA damage proposed in the literature rely on the formation of DNA-adducts [24], the hydrolysis of DNA's phosphate groups [25] and the generation of an oxidative stress leading to DNA damage [26].

After 20 days of exposure to 20, 100 and $500 \mu \mathrm{g}$ U/L a significant increase in DNA damage was observed only for fish exposed to the highest concentration using the comet assay [6]. DNA damage were found in the goldfish C. auratus exposed to $100 \mu \mathrm{g} \mathrm{U} / \mathrm{L}$ during 96h using the same assay [27]. No micronucleus formation was observed in S. salar exposed to $0.25-1 \mathrm{mg} \mathrm{U} / \mathrm{L}$ [28]. In zebrafish cells exposed to $\mathrm{U}$ the phosphorylation of histone $\mathrm{H} 2 \mathrm{AX}$ - a marker of double strand breaks - increased with very high in vitro uranium concentration ranging from 7.1 to $23.8 \mathrm{mg} / \mathrm{L}$ [5]. The results of our study corroborate those from previous studies and show a genotoxic impact in fish exposed to $\mathrm{U}$ concentration as low as $30 \mu \mathrm{g} \mathrm{U} / \mathrm{L}$ which support the sensitivity of the RAPD-PCR method as compared to comet assay and the micronucleus test. 
Gadd45a and rad51 transcriptional responses are increased in Atlantic salmon exposed to $250 \mu \mathrm{g} \mathrm{U} / \mathrm{L}$ [28] and in zebrafish exposed to 20 and $100 \mu \mathrm{g} \mathrm{U} / \mathrm{L}$ [7] indicating a modification in the DNA repair pathway at the transcriptional level. Moreover, the nonhomologous end-joining (NHEJ) pathway is impaired in ZF4 cells exposed to U perturbing the reparability of the DSBs [5]. These repair mechanisms activated upon exposure to DNA damaging chemicals play an important cellular role in maintaining genomic stability. These data suggest that DNA repair pathway is disturbed by $U$ exposure which may explain the increase of DNA alterations found in our study.

\subsection{Genotoxic effects of MeHg}

According to our study, significant changes were observed in the frequency of appearance of PCR products and no difference was found in the number of hybridisation sites in fish after 49 days of exposure to $0.6 \mu \mathrm{g}$ of $\mathrm{Hg} /$ fish/day.

In the environment, mercury may be found in methyl mercury form, produced mainly as the results of methylation of inorganic mercuric form by microorganisms in soil and water [29]. Despite the fact that the $\mathrm{MeHg}$ form is encountered in the aquatic environment and that is highly bio-accumulated through the food web where it exerts toxic actions, there is a clear lack of data on the genotoxic impact of exposure to $\mathrm{MeHg}$ in fish. The inorganic form appears to be more commonly used. A few studies dealt with the genotoxic effect of waterborne exposure to inorganic mercury in fish under laboratory $[28,30,31]$ and in situ [32,33] conditions (Table 5).

Exposure to $81 \mu \mathrm{g} / \mathrm{L}$ of $\mathrm{HgCl}_{2}$ caused significant induction of micronuclei after 24, 48, 72, 96 and 196h in the actinopterygiian fish, Channa punctata [31]. A significant increase in micronuclei frequency was observed in erythrocyte of fish after $96 \mathrm{~h}$ of exposure to 250 $\mu \mathrm{g} / \mathrm{L}$ of $\mathrm{HgCl}_{2}$ [30]. In the wild chubs (Leuciscus cephalus) caught from a metalcontaminated river containing $\mathrm{Hg}$ sediment concentrations in the range of $0.5-5 \mu \mathrm{g} / \mathrm{g}$ and 
polycyclic aromatic hydrocarbons ranging from 0.01 to $0.78 \mu \mathrm{g} / \mathrm{g}$ and increased in DNA damage was observed by the comet test and a high variability in the nuclei frequency [32]. In the golden grey mullet Liza aurata collected from a Hg-contaminated area containing 3.0 to $3.3 \mathrm{mg} \mathrm{Hg} / \mathrm{kg}$ of sediment an increase in DNA damage was found [33]. However the assessment of specific $\mathrm{Hg}$ genotoxicity in the field is compromised by the occurrence of other chemicals. It would have been interesting to have data on $\mathrm{Hg}$ concentrations in prey as $\mathrm{MeHg}$ is highly bio-accumulated in the food web or in water to know about a concentration threshold triggering DNA damage. Field studies rely on the toxicity of a chemical mixture rather than on the toxic effects of a specific contaminant. There is also a large gap in literature regarding studies on DNA damaging effects in fish under realistic exposure conditions. After 21 and 63 days of exposure to dietary $\mathrm{MeHg} 13.5 \mu \mathrm{g}$ of $\mathrm{Hg} / \mathrm{g}, \mathrm{rad} 51$ gene was 2.5 and 10 times up-regulated in liver of zebrafish [3] indicating a change in DNA repair process at the transcriptional level. In the present study, no difference in the number of hybridisation sites was found in fish exposed to methylmercury. However, significant changes in the frequency of appearance of PCR products were observed revealing a genotoxic impact. This is possible since the probe efficiency on a contaminated fish DNA as compared to control DNA is the resultant of both creation and elimination of hybridization sites. For instance, base pair substitution can make appear or disappear such sites. Therefore DNA insults will not necessarily increase the number of hybridization sites.

\subsection{Genotoxic effects of hyperoxia}

In our study, exposure to hyperoxia induces an increase of the number of hybridization sites as compared to control fish. This difference is in the same range of the results found in fish exposed to the lowest concentration of $U$ as compared to the respective control group. After a few days of recovery in a normoxic medium the damage borne by fish genomic DNA exposed to hyperoxia was found not to be permanent since the number of 
micronucleated cells returned to basal level. This is consistent with a recent study [23] showing a decrease in the number of RAPD probe hybridization, the olive moment tail - as observed with the comet assay - and the 8-oxodesoxyguanosine content.

Exposing fish to oxygen-supersaturated water (hyperoxia) may induce the formation of reactive oxygen species (ROS) that may result in oxidative damage to key biological molecules [8]. Despite the evidence that exposure to oxygen increases the levels of ROS $[8,34]$, data regarding the genotoxic effects in fish are scarce. Hyperoxia caused DNA strandbreaks in gills of rainbow trout [35] and in erythrocytes of the mirror carp [11] (Table 5).

The literature shows that an increase in the external oxygen concentration induces the activation of antioxidant defenses. Exposure to hyperoxia induced an increase of SOD activity in rainbow trout [8] and GPX activity in rainbow trout [8] and common carp [11], a decrease in tGSH/GSSG levels in Atlantic salmon [9] and an increase of glycine $\mathrm{N}$ methyltransferase content in the Senegal sole [10]. The effects on the lipid peroxides formation are not clear; some study showed an increase in the goldfish [36] while others found no change in rainbow trout [8].

Beneficial effects of ROS occur at low/moderate concentrations and involve physiological roles in cellular responses like defence against infectious agents, in the function of a number of cellular signalling pathways, and the induction of a mitogenic response [29]. ROS may be involved in normal intracellular signalling of oxygen dependent phenomena [34]. Because of the ambiguous role of ROS in such exposure and the scarcity of data, further experiments on the underlying mechanisms leading to the genotoxic effect of exposure to hyperoxia in aquatic organisms are required.

The present work supports the use of the RAPD-PCR as a sensitive method in the assessment of chemically-induced DNA damage in animals. Moreover the study provides 
novel information regarding on the genotoxicity of low concentration of uranium, $\mathrm{MeHg}$ and oxygen exposure in zebrafish under environmentally relevant scenarios.

\section{Acknowledgements}

The authors are grateful to Jeanette Rotchell for her useful comments and English revision.

\section{References}

[1] F.M.M. Morel, A.M.L. Kraepiel and M. Amyot, The chemical cycle and bioaccumulation of mercury, Annu Rev of Ecol Syst 29 (1998) 543-566.

[2] T.W. Clarkson, L. Magos and G.J. Myers, The Toxicology of Mercury - Current Exposures and Clinical Manifestations, N Engl J Med 349 (2003) 1731-1737.

[3] P. Gonzalez, Y. Dominique, J.C. Massabuau, A. Boudou and J.P. Bourdineaud, Comparative effects of dietary methylmercury on gene expression in liver, skeletal muscle, and brain of the zebrafish (Danio rerio), Environ Sci Technol 39 (2005) 3972-3980.

[4] WHO (World Health Organization), Depleted uranium: Sources, exposure and health effects, WHO/SDE/PHE/01.1, (2001).

[5] S. Pereira, V. Camilleri, M. Floriani, I. Cavalie, J. Garnier-Laplace and C. AdamGuillermin, Genotoxicity of uranium contamination in embryonic zebrafish cells, Aquat Toxicol 109 (2012) 11-16.

[6] S. Barillet, C. Adam-Guillermin, O. Palluel, J.M. Porcher and A. Devaux, Uranium bioaccumulation and biological disorders induced in zebrafish (Danio rerio) after a depleted uranium waterborne exposure, Environ Pollut 159 (2011) 495-502.

[7] A. Lerebours, P. Gonzalez, C. Adam, V. Camilleri, J.P. Bourdineaud and J. GarnierLaplace, Comparative analysis of gene expression in brain, liver, skeletal muscles, 
and gills of zebrafish (Danio rerio) exposed to environmentally relevant waterborne uranium concentrations, Environ Toxicol Chem 28 (2009) 1271-1278.

[8] O. Ritola, D.R. Livingstone, L.D. Peters and P. Lindstrom-Seppa, Antioxidant processes are affected in juvenile rainbow trout (Oncorhynchus mykiss) exposed to ozone and oxygen-supersaturated water, Aquaculture 210 (2002) 1-19.

[9] P.A. Olsvik, T. Kristensen, R. Waagbo, B.O. Rosseland, K.E. Tollefsen, G. Baeverfjord and M.H.G. Berntssen, MRNA expression of antioxidant enzymes (SOD, CAT and GSH-Px) and lipid peroxidative stress in liver of Atlantic salmon (Salmo salar) exposed to hyperoxic water during smoltification, Comp Biochem Physiol C 141 (2005) 314-323.

[10] E. Salas-Leiton, B. Canovas-Conesa, R. Zerolo, J. Lopez-Barea, J.P. Canavate and J. Alhama, Proteomics of juvenile senegal sole (Solea senegalensis) affected by gas bubble disease in hyperoxygenated ponds, Mar Biotechnol 11 (2009) 473-487.

[11] S.A. Mustafa, S.N. Al-Subiai, S.J. Davies and A.N. Jha, Hypoxia-induced oxidative DNA damage links with higher level biological effects including specific growth rate in common carp, Cyprinus carpio L., Ecotoxicol 20 (2011) 1455-1466.

[12] G. Durrieu, R. Maury-Brachet and A. Boudou, Goldmining and mercury contamination of the piscivorous fish Hoplias aimara in French Guiana (Amazon basin), Ecotoxicol Environ Safety 60 (2005) 315-323.

[13] WHO (World Health Organization), Guidelines for drinking-water quality, third edition, Geneva, (2004) 197-209.

[14] S. Barillet, C. Adam, O. Palluel and A. Devaux, Bioaccumulation, oxidative stress, and neurotoxicity in Danio rerio exposed to different isotopic compositions of uranium, Environ Toxicol Chem 26 (2007) 497-505. 
[15] B. Gagnaire, I. Cavalie, V. Camilleri and C. Adam-Guillermin, Effects of Depleted Uranium on Oxidative Stress, Detoxification, and Defence Parameters of Zebrafish Danio rerio, Arch Environ Contam Toxicol 64 (2013) 140-150.

[16] A. Lerebours, C. Adam-Guillermin, D. Brèthes, S. Frelon, M. Floriani, V. Camilleri, J. Garnier-Laplace and J.P. Bourdineaud, Mitochondrial energetic metabolism perturbations in skeletal muscles and brain of zebrafish (Danio rerio) exposed to low concentrations of waterborne uranium, Aquat Toxicol 100 (2010) 66-74.

[17] A. Lerebours, J.P. Bourdineaud, K. Van Der Ven, T. Vandenbrouck, P. Gonzalez, V. Camilleri, M. Floriani, J. Garnier-Laplace and C. Adam-Guillermin, Sublethal effects of waterborne uranium exposures on the zebrafish brain: Transcriptional responses and alterations of the olfactory bulb ultrastructure, Environ Sci Technol 44 (2010) $1438-1443$.

[18] S. Cambier, G. Bénard, N. Mesmer-Dudons, P. Gonzalez, R. Rossignol, D. Brèthes and J.P. Bourdineaud, At environmental doses, dietary methylmercury inhibits mitochondrial energy metabolism in skeletal muscles of the zebra fish (Danio rerio), Int J of Biochem Cell Biol 41 (2009) 791-799.

[19] C.A. de Oliveira Ribeiro, M.D. Nathalie, P. Gonzalez, D. Yannick, B. Jean-Paul, A. Boudou and J.C. Massabuau, Effects of dietary methylmercury on zebrafish skeletal muscle fibres, Environ Toxicol Pharmacol 25 (2008) 304-309.

[20] M. Westerfield A guide for the laboratory use of zebrafish (Danio rerio) 4th ed., The Zebrafish Book University of Oregon Press, Eugene, (2007).

[21] S. Cambier, P. Gonzalez, G. Durrieu and J.P. Bourdineaud, Cadmium-induced genotoxicity in zebrafish at environmentally relevant doses, Ecotoxicol Environ Safety 73 (2010) 312-319. 
[22] B. Geffroy, C. Ladhar, S. Cambier, M. Treguer-Delapierre, D. Brèthes and J.P. Bourdineaud, Impact of dietary gold nanoparticles in zebrafish at very low contamination pressure: The role of size, concentration and exposure time, Nanotoxicology 6 (2012) 144-160.

[23] N. Orieux, S. Cambier, P. Gonzalez, B. Morin, C. Adam, J. Garnier-Laplace and J.P. Bourdineaud, Genotoxic damages in zebrafish submitted to a polymetallic gradient displayed by the Lot River (France), Ecotoxicol Environ Safety 74 (2011) 974-983.

[24] D.M. Stearns, M. Yazzie, A.S. Bradley, V.H. Coryell, J.T. Shelley, A. Ashby, C.S. Asplund and R.C. Lantz, Uranyl acetate induces hprt mutations and uranium-DNA adducts in Chinese hamster ovary EM9 cells, Mutagenesis 20 (2005) 417-423.

[25] M. Yazzie, S.L. Gamble, E.R. Civitello and D.M. Stearns, Uranyl acetate causes DNA single strand breaks in vitro in the presence of ascorbate (vitamin C), Chem Res Toxicol 16 (2003) 524-530.

[26] A.C. Miller, K. Brooks, M. Stewart, B. Anderson, L. Shi, D. McClain and N. Page, Genomic instability in human osteoblast cells after exposure to depleted uranium: Delayed lethality and micronuclei formation, J Environ Radioactivity 64 (2003) 247259.

[27] J. Lourenco, B.B. Castro, R. MacHado, B. Nunes, S. Mendo, F. Gonçalves and R. Pereira, Genetic, biochemical, and individual responses of the teleost fish carassius auratus to uranium, Arch Environ Contam Toxicol 58 (2010) 1023-1031.

[28] Y. Song, B. Salbu, L.S. Heier, H.C. Teien, O.C. Lind, D. Oughton, K. Petersen, B.O. Rosseland, L. Skipperud and K.E. Tollefsen, Early stress responses in Atlantic salmon (Salmo salar) exposed to environmentally relevant concentrations of uranium, Aquat Toxicol 112-113 (2012) 62-71. 
[29] M. Valko, D. Leibfritz, J. Moncol, M.T.D. Cronin, M. Mazur and J. Telser, Free radicals and antioxidants in normal physiological functions and human disease, Int $\mathbf{J}$ Biochem Cell Biol 39 (2007) 44-84.

[30] N. Nagarani, V.J. Devi, C.A. Devi and A.K. Kumaraguru, Genotoxicity Assessment of mercuric chloride in the marine fish Therapon jaruba, EnvironmentAsia 2 (2009) $50-54$.

[31] K.K. Yadav and S.P. Trivedi, Sublethal exposure of heavy metals induces micronuclei in fish, Channa punctata, Chemosphere 77 (2009) 1495-1500.

[32] G. Frenzilli, A. Falleni, V. Scarcelli, I. Del Barga, S. Pellegrini, G. Savarino, V. Mariotti, M. Benedetti, D. Fattorini, F. Regoli and M. Nigro, Cellular responses in the cyprinid Leuciscus cephalus from a contaminated freshwater ecosystem, Aquat Toxicol 89 (2008) 188-196.

[33] C.S.A. Pereira, S.I.A.G. Guilherme, C.M.M. Barroso, L. Verschaeve, M.G.G. Pacheco and S.A.L.V. Mendo, Evaluation of DNA damage induced by environmental exposure to mercury in Liza aurata using the comet assay, Arch Environ Contam Toxicol 58 (2010) 112-122.

[34] M. Nikinmaa, Oxygen-dependent cellular functions - Why fishes and their aquatic environment are a prime choice of study, Comp Biochem Physiol A 133 (2002) 1-16.

[35] A. Liepelt, L. Karbe and J. Westendorf, Induction of DNA strand breaks in rainbow trout Oncorhynchus mykiss under hypoxic and hyperoxic conditions, Aquat Toxicol 33 (1995) 177-181.

[36] V.I. Lushchak, T.V. Bagnyukova, V.V. Husak, L.I. Luzhna, O.V. Lushchak and K.B. Storey, Hyperoxia results in transient oxidative stress and an adaptive response by antioxidant enzymes in goldfish tissues, Int J Biochem Cell Biol 37 (2005) 16701680. 
Table 1. Number of hybridization sites of RAPD probes on individual genomic DNA from control and uranium-contaminated zebrafish. ${ }^{a}$

\begin{tabular}{|c|c|c|c|}
\hline \multirow[b]{3}{*}{ Control } & \multicolumn{2}{|c|}{$\mathrm{OPB}^{\mathrm{b}}$} & OPB11 \\
\hline & $50^{\circ} \mathrm{C}$ & $60^{\circ} \mathrm{C}$ & $50^{\circ} \mathrm{C}$ \\
\hline & $2.5 \pm 0.2$ & $(68 \pm 19) \cdot 10^{-6}$ & $(2.6 \pm 0.4) \cdot 10^{-3}$ \\
\hline $30 \mu \mathrm{g} \mathrm{U} / \mathrm{L}$ & $2.3 \pm 0.2$ & $(365 \pm 88) \cdot 10^{-6} *$ & $(3.4 \pm 1.3) \cdot 10^{-3}$ \\
\hline $100 \mu \mathrm{g} \mathrm{U} / \mathrm{L}$ & $3.2 \pm 0.3$ & $(800 \pm 214) \cdot 10^{-6} *$ & $(3.9 \pm 1.0) \cdot 10^{-3}$ \\
\hline
\end{tabular}

${ }^{\mathrm{a}}$ Numbers correspond to a genome unit, i.e. to a cell nucleus. Ten zebrafish genomic DNAs were isolated for each condition. Asterisks indicate a significant difference between a contaminated fish DNA and a control one $(p<0.05) .{ }^{\mathrm{b}}$ The hybridization temperature set for the RAPD-PCR is indicated. 
Table 2. Classification according to the temperature intervals to which their $T_{m}$ belong, of the PCR products obtained with OPB7 probe on individual genomic DNA from control and uranium-contaminated zebrafish.

\begin{tabular}{|c|c|c|c|}
\hline Temperature intervals & Control $^{b}$ & $30^{b}$ & $100^{b}$ \\
\hline$[74-78[$ & 0.7 & 0.7 & 0.9 \\
\hline [78-80[ & 0.5 & 0.8 & 0.5 \\
\hline [80-81[ & 0 & 0 & 0 \\
\hline [81-82[ & 1 & 1 & 1 \\
\hline [82-83[ & 0 & 0 & 0 \\
\hline [83-84[ & 0 & 0 & 0 \\
\hline$[84-85[$ & 0.5 & 0.4 & 0.6 \\
\hline [85-86[ & 0.5 & 0.3 & 0.2 \\
\hline [86-87[ & 0.2 & $0.6^{*}$ & $0.9 *$ \\
\hline [87-88[ & 0.5 & 0.4 & $0.1 *$ \\
\hline [88-89[ & 0.5 & 0.3 & 0.3 \\
\hline
\end{tabular}

${ }^{a}$ The hybridization temperature set for the RAPD-PCR was $60^{\circ} \mathrm{C}$. Ten zebrafish genomic DNAs were isolated for each condition. Asterisks indicate a significant difference between a contaminated fish DNA and a control one $(p<0.05)$.

${ }^{b}$ Numbers indicate the frequency of appearance of a PCR product in each temperature interval as recorded among the 10 zebrafish of a given exposure condition. 
Table 3. Number of hybridization sites of RAPD probes on individual genomic DNA from from control, methylmercury-contaminated (13.5 $\mu \mathrm{g}$ $\mathrm{Hg} / \mathrm{g}$ ) and oxygen-exposed zebrafish. ${ }^{\mathrm{a}}$

\begin{tabular}{|c|c|c|c|}
\hline \multirow[b]{3}{*}{ Control } & \multicolumn{2}{|c|}{$\mathrm{OPB}^{\mathrm{b}}$} & OPB11 \\
\hline & $50^{\circ} \mathrm{C}$ & $60^{\circ} \mathrm{C}$ & $50^{\circ} \mathrm{C}$ \\
\hline & $0.72 \pm 0.04$ & $(30 \pm 5) \cdot 10^{-6}$ & $(7.3 \pm 0.7) \cdot 10^{-3}$ \\
\hline $\mathrm{MeHg}$ & $0.68 \pm 0.04$ & $(17 \pm 4) \cdot 10^{-6}$ & $(6.8 \pm 0.5) \cdot 10^{-3}$ \\
\hline $\mathrm{O}_{2}$ & $0.75 \pm 0.08$ & $(371 \pm 113) \cdot 10^{-6} *$ & $(4.8 \pm 0.5) \cdot 10^{-3} *$ \\
\hline
\end{tabular}

${ }^{\mathrm{a}}$ Numbers correspond to a genome unit, i.e. to a cell nucleus. Ten zebrafish genomic DNAs were isolated for each condition. Asterisks indicate a significant difference between a treated fish DNA and a control one ( $p<$ $0.05){ }^{\mathrm{b}}$ The hybridization temperature set for the RAPD-PCR is indicated. 
Table 4. Classification according to the temperature intervals to which their $\mathrm{T}_{\mathrm{m}}$ belong, of the PCR products obtained with OPB7 and OPB11 probes on individual genomic DNA from control, methylmercury-contaminated and oxygen-exposed zebrafish. ${ }^{\mathrm{a}}$

\begin{tabular}{|c|c|c|c|c|c|c|}
\hline \multirow[b]{2}{*}{$\begin{array}{l}\text { Temperature } \\
\text { intervals }\end{array}$} & \multicolumn{3}{|c|}{ OPB7 } & \multicolumn{3}{|c|}{ OPB11 } \\
\hline & Control $^{b}$ & $\mathrm{MeHg}^{\mathrm{b}}$ & $\mathrm{O}_{2}{ }^{\mathrm{b}}$ & Control $^{b}$ & $\mathrm{MeHg}^{\mathrm{b}}$ & $\mathrm{O}_{2}{ }^{\mathrm{b}}$ \\
\hline [70-71[ & 0.3 & 0.3 & 0.2 & 0.22 & 0.4 & 0.4 \\
\hline$[71-72[$ & 0.3 & 0.4 & 0.6 & 0.78 & 0.3 & 0.3 \\
\hline$[72-73[$ & 0.4 & 0.2 & 0.2 & 0.11 & 0.1 & 0.1 \\
\hline [73-74[ & 0.4 & 0.6 & 0.2 & 0 & 0.3 & 0.1 \\
\hline$[74-75[$ & 0.4 & 0.1 & 0.6 & 0.78 & $0.1^{*}$ & 0.5 \\
\hline [75-76[ & 0 & $0.5^{*}$ & 0 & 0.22 & 0.1 & 0 \\
\hline [76-77] & 0.6 & $0 *$ & 0.3 & 0 & 0.1 & 0.2 \\
\hline$[77-78[$ & 0.2 & 0.4 & 0.2 & 0.33 & 0.6 & 0.1 \\
\hline$[78-79[$ & 0.2 & 0.1 & 0 & 0.11 & 0.2 & 0 \\
\hline [79-80[ & 0 & 0 & 0 & 0 & 0 & 0.3 \\
\hline [80-81[ & 0.1 & 0.2 & 0 & 0.78 & 0.7 & 0.6 \\
\hline [81-82[ & 0.8 & 0.7 & 0.9 & 0.11 & 0 & 0 \\
\hline [82-83[ & 0 & 0 & 0 & 0.56 & 0.7 & 0.7 \\
\hline [83-84[ & 0.1 & 0.2 & 0.1 & 0.33 & 0.4 & 0.3 \\
\hline [84-85[ & 0.6 & 0.7 & 0.7 & 0.22 & 0.2 & 0.3 \\
\hline$[85-86[$ & 0.1 & 0.1 & 0.1 & 0 & 0.2 & 0.2 \\
\hline [86-87[ & 0.9 & 0.7 & 0.9 & 0.33 & 0.2 & 0.4 \\
\hline [87-88[ & 0.1 & 0 & 0 & 0.56 & 0.7 & 0.5 \\
\hline [88-89[ & 1 & 1 & 1 & 0 & 0 & 0 \\
\hline [89-90[ & 0 & 0 & 0 & 0.11 & 0 & 0.3 \\
\hline [90-91[ & 0 & 0 & 0 & 0.89 & 0.9 & 0.9 \\
\hline [91-92[ & 1 & 1 & 1 & 0 & 0 & 0 \\
\hline
\end{tabular}

${ }^{a}$ The hybridization temperature set for the RAPD-PCR was $60^{\circ} \mathrm{C}$ using OBP7 and $50^{\circ} \mathrm{C}$ using OPB11. Ten zebrafish genomic DNAs were isolated for each condition. Asterisks indicate a significant difference between a treated fish DNA and a control one $(p<0.05)$.

b Numbers indicate the frequency of appearance of a PCR product in each temperature interval as recorded among the 10 zebrafish of a given exposure condition. 
Table 5. Genotoxic effects assessed by comet assay and/or micronucleus test in fish in vivo or in situ exposed to $\mathrm{Hg}, \mathrm{U}$ and hyperoxia.

\begin{tabular}{|c|c|c|c|c|}
\hline Biological model & Exposure condition & Method & Results & Reference \\
\hline Mirror carp & In vivo exposure to & Comet assay & Modifications of & Mustafa et \\
\hline Cyprinus carpio & $\begin{array}{l}12.3 \pm 0.5 \mathrm{mg} \mathrm{O}_{2} / \mathrm{L} \\
\text { for } 30 \text { days }\end{array}$ & $\begin{array}{l}\text { (erythrocytes), } \\
\text { GPx activity } \\
\text { (plasma, liver), } \\
\text { TEM (gills, liver) }\end{array}$ & $\begin{array}{l}\text { GPx activity, } \\
\text { Increase in DNA } \\
\text { damage }(25 \%) \text {, } \\
\text { tissue damage }\end{array}$ & al., (2011) \\
\hline $\begin{array}{l}\text { Rainbow trout } \\
\text { Oncorhynchus } \\
\text { mykiss }\end{array}$ & $\begin{array}{l}\text { In vivo exposure to } \\
3.3 \text { to } 21.1 \mathrm{mg} \mathrm{O}_{2} / \mathrm{L}\end{array}$ & $\begin{array}{l}\text { Alkaline } \\
\text { unwinding } \\
\text { method }\end{array}$ & $\begin{array}{l}\text { Increases observed } \\
\text { particularly under } \\
\text { hyperoxic } \\
\text { conditions }\end{array}$ & $\begin{array}{l}\text { Liepelt et al., } \\
\text { (1995) }\end{array}$ \\
\hline $\begin{array}{l}\text { Golden grey mullet } \\
\text { Liza aurata }\end{array}$ & $\begin{array}{l}\text { In situ exposure to } \\
\mathrm{Hg}, 3.0 \text { to } 3.3 \mathrm{ng} \\
\mathrm{Hg} / \mathrm{mg} \text { of sediment } \\
\text { (dry weight) }\end{array}$ & $\begin{array}{l}\text { Comet assay } \\
\text { (erythrocytes) }\end{array}$ & $\begin{array}{l}\text { Increase in DNA } \\
\text { damage }\end{array}$ & $\begin{array}{l}\text { Pereira et al., } \\
(2010)\end{array}$ \\
\hline $\begin{array}{l}\text { Chubs Leuciscus } \\
\text { cephalus }\end{array}$ & $\begin{array}{l}\text { In situ exposure to } \\
\mathrm{Hg}, 0.5 \text { to } 5 \mu \mathrm{gHg} / \mathrm{g} \\
\text { of sediment }\end{array}$ & $\begin{array}{l}\text { Comet assay } \\
\text { (erythrocytes) } \\
\text { Micronucleus test } \\
\text { (erythrocytes) }\end{array}$ & $\begin{array}{l}\text { Increase in DNA } \\
\text { damage, no change } \\
\text { in the frequency of } \\
\text { micronuclei }\end{array}$ & $\begin{array}{l}\text { Frenzilli et } \\
\text { al., (2008) }\end{array}$ \\
\hline $\begin{array}{l}\text { Spotted snakehead } \\
\text { Channa punctata }\end{array}$ & $\begin{array}{l}\text { In vivo exposure to } \\
0.081 \mathrm{mgHg} / \mathrm{L} \text { for } \\
24,48,72,96 \text { and } \\
168 \mathrm{~h}\end{array}$ & $\begin{array}{l}\text { Micronucleus test } \\
\text { (erythrocytes) }\end{array}$ & $\begin{array}{l}\text { Increase in the } \\
\text { frequency of } \\
\text { micronuclei }\end{array}$ & $\begin{array}{l}\text { Yadav and } \\
\text { Trivedi, } \\
\text { (2009) }\end{array}$ \\
\hline $\begin{array}{l}\text { Jarbua Terapon } \\
\text { Therapon jarbua }\end{array}$ & $\begin{array}{l}\text { In vivo exposure to } \\
0.125 \text { and } 0.25 \\
\mathrm{mgHg} / \mathrm{L} \text { for } 96 \mathrm{~h}\end{array}$ & $\begin{array}{l}\text { Micronucleus test } \\
\text { (erythrocytes) }\end{array}$ & $\begin{array}{l}\text { Increase in the } \\
\text { frequency of } \\
\text { micronuclei for the } \\
\text { highest exposure }\end{array}$ & $\begin{array}{l}\text { Nagarani et } \\
\text { al., (2009) }\end{array}$ \\
\hline $\begin{array}{l}\text { Atlantic salmon } \\
\text { Salmo salar }\end{array}$ & $\begin{array}{l}\text { In vivo exposure to } \\
0.25,0.5 \text { and } 1.0 \\
\mathrm{mg} / \mathrm{L} \text { of waterborne } \\
\mathrm{U} \text { (uranyl acetate) } \\
\text { for } 48 \mathrm{~h}\end{array}$ & $\begin{array}{l}\text { Micronucleus test } \\
\text { (blood cells) }\end{array}$ & No change & $\begin{array}{l}\text { Song et al., } \\
\text { (2012) }\end{array}$ \\
\hline $\begin{array}{l}\text { Goldfish Carassius } \\
\text { auratus }\end{array}$ & $\begin{array}{l}\text { In vivo exposure to } \\
0.1,0.45 \text { and } 2.025 \\
\text { mg/L of waterborne } \\
\text { U (uranyl nitrate) for } \\
96 \mathrm{~h}\end{array}$ & $\begin{array}{l}\text { Comet assay } \\
\text { (erythrocytes) }\end{array}$ & $\begin{array}{l}\text { Increase in DNA } \\
\text { damage after } 96 \mathrm{~h} \\
\text { exposure period }\end{array}$ & $\begin{array}{l}\text { Lourenço et } \\
\text { al., (2010) }\end{array}$ \\
\hline $\begin{array}{l}\text { Zebrafish Danio } \\
\text { rerio }\end{array}$ & $\begin{array}{l}\text { In vivo exposure to } \\
20,100 \text { and } 500 \\
\mu \mathrm{g} / \mathrm{L} \text { of waterborne } \\
\text { depleted } \mathrm{U} \text { (uranyl } \\
\text { nitrate) for } 5,10 \text { and } \\
20 \text { days }\end{array}$ & $\begin{array}{l}\text { Comet assay } \\
\text { (erythrocytes) }\end{array}$ & $\begin{array}{l}\text { Decrease in DNA } \\
\text { damage after } 5 \\
\text { days for the three U } \\
\text { exposures, Increase } \\
\text { in DNA damage } \\
\text { after } 20 \text { days of } \\
\text { exposure to } 500 \\
\mu \mathrm{gU} / \mathrm{L}\end{array}$ & $\begin{array}{l}\text { Barillet et al., } \\
\text { (2011) }\end{array}$ \\
\hline
\end{tabular}




\section{Supplementary material}

Table S1. Uranium concentration in $\mathrm{ng} / \mathrm{g}$ tissue dry weight.

\begin{tabular}{ccc}
\hline & Muscles & Brain \\
\hline Control & $16 \pm 10$ & $20 \pm 10$ \\
$30 \mu \mathrm{g} \mathrm{U} / \mathrm{L}$ & $373 \pm 142$ & $393 \pm 407$ \\
$100 \mu \mathrm{g} \mathrm{U} / \mathrm{L}$ & $1546 \pm 1022 *$ & $816 \pm 597 *$ \\
\hline$*$ significant difference as compared to control \\
$(p<0.05 ; n=5 ;$ means \pm standard deviation $)$ \\
\hline
\end{tabular}


Table S2. Total mercury concentration in $\mu \mathrm{g} / \mathrm{g}$ tissue dry weight in control fish and fish dietary exposed to $13.5 \mu \mathrm{g} \mathrm{Hg} / \mathrm{g}$.

\begin{tabular}{ccc}
\hline & Muscles & Brain \\
\hline Control & $1.9 \pm 0.6$ & $1.0 \pm 0.1$ \\
Exposed & $36 \pm 4 *$ & $46 \pm 7 *$ \\
\hline$*$ significant difference as compared to control \\
$(p<0.05 ; n=5 ;$ means \pm standard deviation $)$ \\
\hline
\end{tabular}

